\title{
Developing five-minute message through co-curriculum activities
}

\author{
Shahrulfadly Rustam*, Mohar Kassim \\ Centre for Coaching Science, National Defence University of Malaysia, 57000 Kuala Lumpur, Malaysia
}

\section{A R T I C L E IN F O}

\section{Article history:}

Received 6 September 2016

Received in revised form

26 October 2016

Accepted 6 November 2016

\section{Keywords:}

Value of virtues

Virtues module

Co-curricular activity

Police cadet unit

\begin{abstract}
A B S T R A C T
The main objective of this study is to find out the ability of understanding and application about the value of virtues among school students, through the five-minute message virtues module in using on the co-curricular activities. Second objective is to compare the different ability to understand and application the value of virtues between pre-test and post-test among subject. 32 male respondent $(\mathrm{N}=32)$ are involved in this study including form four and form five students of MARA Junior Science College Malaysia Pasir Salak branch. The samples are chosen by purposive technique, which the respondent was the member of School Police Cadet Unit. Questionnaire was used at the instrument in this study. The questionnaire was divided into two sections. That is section A is related to students' background while section B is about the situation at applying the value of virtues. The methodology that being used in this study is quantitative style with quasi-experiment and descriptive to see the effectiveness of module in pre-test and post-test. The questionnaire was analysed using the SPSS software version 22 to calculate the mean and standard deviation. To see the different ability to understand and application the value of virtues, independent samples $t$ was used. The value of reliability for this study instrument was $r=0.884$. The findings showed post-test mean $(M=6.84)$ in understanding and application the value using the five-minute message virtues module is better than pre-test mean $(\mathrm{M}=6.55)$ value using the five-minute message virtues module, in extracurricular activities. The implication at this study, value of five-minute message virtues module is able to show the understanding and the application in the value of virtues in students' lifetime.
\end{abstract}

(C) 2016 The Authors. Published by IASE. This is an open access article under the CC BY-NC-ND license (http://creativecommons.org/licenses/by-nc-nd/4.0/).

\section{Introduction}

\subsection{Values concepts}

Values are ideas or convictions about attractive end states or practices that rise above particular circumstances, guide determination or assessment of conduct and occasions, and are requested by relative significance (Schwartz, 1996). In the previous two decades, individual values have been the focus of an extensive variety of studies, specifically those by Schwartz and partners (e.g., Schwartz, 1992, 1994; Schwartz and Bilsky, 1990; Schwartz and Boehnke, 2004; Schwartz et al., 2001; Sagiv and Schwartz, 2000). Expanding on Rokeach's (1973) work, Schwartz's Values System (SVS) distinguishes 10

\footnotetext{
* Corresponding Author.

Email Address: shahrulfadly@upnm.edu.my (S. Rustam)

https://doi.org/10.21833/ijaas.2016.11.010

2313-626X/C 2016 The Authors. Published by IASE.

This is an open access article under the CC BY-NC-ND license

(http://creativecommons.org/licenses/by-nc-nd/4.0/)
}

esteem sorts mirroring a continuum of related inspirations: Self-course, Stimulation, Hedonism,

Achievement, power, security, conformity, tradition, benevolence, and universalism; this continuum is spoken to as a two dimensional, roundabout structure.

Values can be characterized as great behavior, society and morals of the human individual in connection to other people, nature and God. Ethical values are presumptions about things they longed for and in the meantime it is likewise a paradigm or measure. Estimations of a general public are normally taking into account religion. It is the point of all religions, to frame life adherents to be great and decent; Kassim and Rustam (2015) state that values are always positive in nature and can be accepted by the community including students.

In education system at Malaysia, educational values, were formally initially highlight through Cabinet Report 1989, which at that time Datuk Seri Anwar Ibrahim held the reins of the Ministry of Education where he made a articulation on the Philosophy of Education (FPN) and SSIC, which fused 
the issues of values to be implement to students and teachers in making a stable and amicable individuals, not just as far as scholarly, additionally enthusiastic, otherworldly and physical.

The substance of the National Education Policy (FPN) in its written form in 1987 expressed that "Education in Malaysia is an ongoing effort towards the development of the potential of individuals in a holistic and integrated in order to create a balanced and harmonious intellectual, spiritual, physical and emotional based on the belief and obedience to God. Effort is designed to produce Malaysian citizens who are knowledgeable, knowledgeable, competent, responsible and capable of achieving well-being and contribute to the harmony and prosperity of society and the nation." Educators are not just showing obligations contained just in the syllabus, in light of the fact that the values have found in every subject. Furthermore, there are times, amplified values are discovered particularly in the subject yet not formally connected as through co-curricular activities and great correspondence amongst educators and students that will influence the improvement of the student life.

In Malaysia, right now, the issue of how to apply these values is turning out to be more evident and charmed. The Ministry of Education has received a technique where the utilization of qualities is done thoroughly. Values will be imbued in all subjects through formal and informal teachings, and will be further reinforced through co-curricular activities. Outside of the classroom, values will be acquainted in an incorporated way with guarantee the reception of the values is fruitful and successful.

Co-curricular activities were to be a fundamental part of the school life. The activities supported or perceived by a school were not a part of the scholarly educational programs but rather were recognized to be a vital piece of life of an instructive foundation which incorporates games, school groups, understudies' daily papers, and so forth. Cocurricular activities were useful for the teacher student's relations and within the sight of these activities students performed better in studies. Educators get more opportunity to comprehend their students. They become acquainted with various sides of their students other than studies. Instructors get favourable circumstances from them as they could help other people with their thoughts and nearness (Cowley, 2005).

A co-curricular activity is characterized as a system or out-of-class action, administered and or financed by the school, which gives educational modules related learning and character building encounters. Co-curricular activity is deliberate, are not part of the consistent school educational modules, are not reviewed and don't gain credits. At the end of the day, "Co-curricular activity" implies activity directed on or off school premises by clubs, affiliations, and associations of students supported by the Board of Education. "Co-curricular activities" additionally incorporates the students' clubs, affiliations, and associations that lead those activities.

Co-curricular activities are a piece of the school educational modules and each student ought to take part in this action. The activity can be completed in the classroom or outside the classroom, contingent upon the sorts of activity arranged and executed. With the supposition that the students do not get information or values in the classroom, then the additional curricular programme can give an abundance of information and experience for mental advancement, gifts, physical, profound and stylish and positive social qualities arrangement in the students. Co-curricular activity may regularly additional trust to activity for school students are a way to improve social collaboration, health recreation, leadership, self-confident and selfdiscipline.

Jamalis and Fauzee (2007) stated in Malaysia there is an emphasis on obligation in after-school activities and teachers are expected to conduct extra-curriculum activities which are compulsory to school children. However, within these extra curriculum framework students are free to choose from three categories of after-school activity: clubs and societies, the uniformed bodies and sports. The English language society, recreational society and history society are examples of the clubs and societies, while the uniformed bodies comprise activities such as scouts, brownies, Red Crescent, and army cadets. Sports activities are probably the most wide-ranging and comprise anything from soccer, hockey and volleyball to track and field activities. In addition, Kassim (2008) stated that training are elements of the coaching process and become important indicators for the hard work undertaken by the athletes to enhance performance.

Co-curricular activities serve as a stage that expects to balance between academic and development of non-specific aptitudes in students in schools. Co-curricular activities are the exemplification of learning attributes and values contained in the educational programs. What is sustained in the co-curricular activities does not just underscore adjusted information highlighted with profound and human values, additionally the harmony between the formal qualities of scholarly educational programs with casual attributes of cocurricular activities. Instructing and learning guided by the educational programs is actualized either through games and recreations, clubs and social orders, formally dressed bodies, or support in exercises outside of the school.

\subsection{The problem of the study}

Deterioration of discipline among students is often a topic of conversation and published in newspapers; the students now, especially secondary level less practice good values in their daily lives. If the problem is not overcome, it would be a serious syndrome. What's more, since lately we often served with social symptoms get worse, particularly in the 
problem of baby abandonment, adultery, skipping school, smoking, bullying, fighting teachers, vandalism and other moral collapse that often occurs among students. All educators are advised to help students who are troubled with how to create a healthy competitive element in school through various activities and programs that enhance awareness, increase two-way communication skills and help in decision making skills. Among the factors that make students not interested in teaching and learning in the school and school hated is because the school is a boring place and cannot meet students' preferences.

Warnock and Norwich (2010) stated the disciplinary problems at school and moral issues to a boil. This problem is increasingly seen to increase. As is well known immoral activities, record video porn, rape, illegal racing, drug abuse and murder are among the social problems of the youth that raged in our country now. We are often featured in the media about these things. This occurs due to less application of moral values among the youth and lack of self-awareness in the teenager.

Schools should aim for a holistic curriculum that builds up a youngster rationally, physically, socially and ethically with the goal that they can fit in the public eye and the universe of work. In any case, there are times when the scholastic side of the educational programs is stressed increasingly that alternate components. Regardless of the inconsistence in discoveries, a significant number of the studies led need to date indicated the constructive outcomes of co-curricular activities on scholastic achievement. However, numerous partners in the educational system appear to be of the conviction that co-curricular activities devour scholastic time superfluously.

\subsection{The goal of the study}

This study wants to analyze the aspect of moral values through students' participation in cocurricular activity especially in the school police cadet unit. The study examines level of values application through the module five-minute message among male student in the school police cadet unit. It also looks at how students appreciate the values that are promoted or enhanced by their school.

\section{Method}

\subsection{Research design}

The study used the quasi-experimental and a survey method to lead this research. Quasiexperimental method is utilized to assess the efficacy of the message in module values when respondents to the study could not be haphazardly allotted. Quasi-experimental design was used to supplant the configuration of an exploratory immaculate when during the time spent selecting respondents to the survey, an irregular conveyance is impossible by the researcher (Chua, 2006).

Additionally, this study was directed on people who are always presented to the outer mistakes, for instance, gender, age, situation, past experience, existing information, and the impact of the environment and so on. All these variables can influence the result of the analysis. On the other hand, researchers are not certain if and adjustment in the treatment bunch respondents toward the end of the examination was because of the treatment given to him or outer components other. This study outline was quasi-experimental study with pre-test and test-post design with non-identical control group (non-proportionate pretest and posttest control group design (Campbell and Stanley, 1963; Wiersma et al., 1991).

Research design is utilized as the subject of quasi elected intact group (Wiersma, 2000). This implies subjects were not haphazardly appointed (Johnson and Christensen, 2000). Intended design is utilized to test the viability of the message module qualities to the control and treatment bunches in grasping the act of qualities through co-curricular activities in School Police Cadet Unit. Survey method using questionnaire created by the researcher themselves through a pilot study that was led to decide the dependability and legitimacy of the survey. To play out the exploration, the researcher utilized survey for social event data rapidly and pick up top to bottom investigation of the issues. Respondents just need to determine the genuine circumstance based inquiries.

\subsection{Subject characteristic}

The sample utilized in this research is students of MARA Junior Science College Pasir Salak. The sampling technique utilized purposive sampling, used 32 male students of MARA Junior Science College Pasir Salak from the Police Cadet Unit. 32 students were used as the control group and the treatment group to test the message in the fiveminute message virtues module that generated values.

\subsection{Sampling procedures}

To choose the samples, purposive sampling was utilized. 32 male students from the MARA Junior Science College Pasir Salak Police Cadet unit were picked as participants. These students were gathered into control and treatment group; to test whether the module is effective in creating great qualities.

This study took 12 weeks and it was completed at the Mara Junior Science College Pasir Salak Perak. Written materials were carefully arranged and the survey was developed exclusively for this study. The procedure to execute the module took 12 weeks incorporating gatherings with the participants from the formally dressed body, the Police cadets' unit. The consultation was led 3 times each week. In every meeting, the samples were guided to perform the 
values as expressed in the module. Writing and presentation of research data and preparing research report took 3 weeks.

\subsection{Measure procedures}

The intention for this study is to test the adequacy of the message module values in the act of applying good values to students through cocurricular activities at the MARA Junior Science Colleges Pasir Salak. Researcher utilizes the module that produced the message of values and a questionnaire as an exploration instrument. To Led research instrument is isolated into two; virtues module (five-minute message virtues module) and questionnaire with a specific end goal to gather quantitative information respondents.

The questionnaire comprised of two sections, section A contains 3 items about respondents' data. Part B contains 80 things that evaluate the level of application of the values of respondents. Section A of the questionnaire is connected inquiries demographic, for example, sexual orientation, age and race. Part B questions related situation of application the act of good values that incorporate self-reliant, high courtesy, respect, freedom, goodheart, courage, justice, love, honesty, cooperation, physical and mental hygiene, diligence, gratitude, awareness, rationality and society.

This questionnaire was analyzed validity and reliability of the item through a pilot study was done in which the reliability of the survey item through alpha cronbach's $r=0.884$. High unwavering quality of the questionnaire must exceed $r=0.80$. Part $B$ comprises of 80 things of the 10 -point scale of 1 to 10 where 1 state to not agree and an estimation of 10 state to strongly agree. This is expected to inspire the level of routine of respondent's values through five-minute virtues module produced values.

\section{Result and discussion}

Data analysis will include a few stages of storing data, give the code, isolating the data, make assessment and examine data. All questionnaires that contain the answers will be gathered and coded. Modifications to the questionnaire will be done to guarantee that each answer is finished and as per set up methods. Data structure in this study was a quantitative data including respondent's experience, and the act of respondent qualities.

These data are measured as far as genuine numbers according to a ten-point scale of estimation for every variable. The data analysis for this study was led by utilizing Statistical Package for the Social Sciences Version 22.0 descriptive measured were run to see an examination of male means between pretest and posttest. To see the level of comprehension students' values through application five-minute virtues module, every aspect of students practice values was analyzed. The results are shown in Tables 1, 2, and 3.
Table 1: Methods of data analysis

\begin{tabular}{|c|c|c|}
\hline Part & Analysis type & Measurement tools \\
\hline A & $\begin{array}{l}\text { Background data of } \\
\text { respondent }\end{array}$ & $\begin{array}{l}\text { Frequency, } \\
\text { percentage }\end{array}$ \\
\hline B & $\begin{array}{l}\text { The level of application five } \\
\text { minute message virtues } \\
\text { module and the comparing } \\
\text { the level of application five } \\
\text { minute message virtues } \\
\text { module between pretest } \\
\text { and posttest }\end{array}$ & $\begin{array}{l}\text { Mean pretest and } \\
\text { posttest, }\end{array}$ \\
\hline
\end{tabular}

Table 2: Overall mean, standard deviation and mean differences in the pretest and posttest among male students

\begin{tabular}{|c|c|c|c|c|c|}
\hline Subject & \multicolumn{1}{c}{$\mathrm{N}$} & \multicolumn{1}{c}{ Test } & \multicolumn{1}{c|}{ Mean } & $\begin{array}{c}\text { Standard } \\
\text { deviation }\end{array}$ & $\begin{array}{c}\text { Mean } \\
\text { differences }\end{array}$ \\
\hline Male & 32 & Pre & 6.55 & .614 & .040 \\
& & Post & 6.84 & .634 & .062 \\
\hline
\end{tabular}

Table 3: Mean score of pretest and posttest respondents' application of values among male respondent through the five-minute message module

\begin{tabular}{|c|c|c|}
\hline Application values & \multicolumn{1}{c}{$\begin{array}{c}\text { Pretest } \\
\text { Male mean }\end{array}$} & $\begin{array}{c}\text { Posttest } \\
\text { Male mean }\end{array}$ \\
\hline Good heart & 7.84 & 7.93 \\
\hline Independently & 5.87 & 6.53 \\
\hline High manner & 6.93 & 7.08 \\
\hline Respect & 6.31 & 6.68 \\
\hline Love & 6.31 & 6.68 \\
\hline Justice & 6.61 & 6.64 \\
\hline Freedom & 6.90 & 7.91 \\
\hline Courage & 6.59 & 6.70 \\
\hline Physical and mental hygiene & 6.35 & 7.23 \\
\hline Honesty & 6.80 & 6.97 \\
\hline Diligence & 6.80 & 7.04 \\
\hline Cooperation & 7.48 & 7.91 \\
\hline Awareness & 5.88 & 6.00 \\
\hline Gratitude to god & 6.55 & 6.61 \\
\hline Rational & 5.43 & 6.46 \\
\hline Social & 5.24 & 5.74 \\
\hline Mean overall module & 6.55 & 6.84 \\
\hline
\end{tabular}

\section{Conclusion}

Individual values need emerge out of adjustment to life experiences. Adjustment may appear as redesigning feasible values and minimizing upset values. In any case, the converse happens with values that worry material prosperity and security. Socio-demographic qualities add to clarifying individual contrasts in worth needs since they speak to various arrangements of life experiences. With regards to the structure of values recognized by the hypothesis, precursors influence needs in an efficient way. They tend to upgrade the significance of values that are nearby in the worth circle such as congruity and security, however to undermine the significance of the contending values for instance self-course and incitement.

The objective of the National Education Policy is to make a people-oriented Malaysians joined together and regarded and to practice great values in ordinary life. This objective could be accomplished if the more youthful era, particularly the students will be given an adjusted and finish instruction of the 
physical, enthusiastic, profound, scholarly and social. Education splendidly adjusted and dependably respected these two parts of scholarly and cocurricular activities. To advance and upgrade the act of honorable values co-curricular activities and accentuation ought to be given genuine consideration.

An Emphasis educational programs in schools is fitting to the times and the requirements of instruction in our nation. Furthermore, the objective of the Human Capital Development in the Education Development Master Plan 2006-2010 which concentrates on supporting students to gain abilities and skills and usage procedure in underlining values including health, safety and cleanliness in instructing and learning exercises educational programs. Actualized an activity arrangement around there is underscores the values and safety, health and cleanliness in instructing and learning. Level of execution required in this activity arrangement is the quantity of students who rehearse great values and accomplishment results are found to increment in 2010.

This proves the act of good values is an essential angle in a person and students is a key during the time spent of teaching and learning in schools. Values can be connected to students either through experience or study. Thus, the values ought to be accentuated in a particular structure, for example, through co-curricular activities are very much arranged and focused. Perform moral values ought to be given a clarification and must be sustained so it mixed with the capability of regular life of students.

Alluding to the discoveries of the study it can be reasoned that the five-minute message modules positively affect the students in the act of acknowledging values through co-curricular activities. The instruction educational modules ought to be given more consideration since it includes full contribution of students and practice great values can be acknowledged completely by making a module message five minutes hone great values in additional curricular activities. This should be adjusted to the proficient and viable administration to guarantee that the goals and objectives set to be accomplished.

This will add to the upgrade of students' values, for example, thoughtfulness, sympathy, participation, independence, and rational parts of alternate values. This additionally will straightforwardly add to the push to create future leaders of the high and respectable values can add to peace and congruity and success of the country and society.

\section{Acknowledgements}

I would like to convey my hearties appreciation to the Centre of Coaching Science, and the Research and Innovation Division of the National Defence University of Malaysia for giving me the opportunity to conduct and publish the result of this research.

\section{References}

Campbell DT and Stanley JC (1963). Experimental and quasi-experimental design for research. Houghton Mifflin Company, Hopewell, USA.

Chua YP (2006). Basic Research Statistic. McGrawHill Education, Shah Alam, Malaysia.

Cowley S (2005). How to survive your first year in teaching. Continuum, New York, USA.

Jamalis M and Fauzee MSO (2007). Developing Human Value through Extra-Curricular Activities. The Journal of Human Resource and Adult Learning, 3(1): 53-60.

Johnson RB and Christensen LB (2000). Educational research: Quantitative and qualitative approaches. Allyn and Bacon, Boston, USA.

Kassim M (2008). A qualitative study of the relationship between the knowledge and behaviour of coaches in two football academies in Malaysia. Ph.D. dissertation, Loughborough University, United Kingdom.

Kassim M and Rustam S (2015). Inculcation of values in co-curricular activities from virtues module. Journal of Scientific Research and Development, 2(13): 183-188.

Rokeach M (1973). The nature of human values. Free Press, New York, USA.

Sagiv L and Schwartz SH (2000). Value priorities and subjective well-being: Direct relations and congruity effects. European Journal of Social Psychology, 30(2): 177-198.

Schwandt TA (1994). Are there universal aspects in the content and structure of values. Journal of Social Sciences, 50(1): 19-45.

Schwartz SH (1992). Universals in the content and structure of values: Theory and empirical tests in 20 countries. In Zanna M (Eds.), Advances in experimental social psychology: 1-65. Academic Press, New York, USA.

Schwartz SH (1996). Value priorities and behavior: Applying a theory of integrated value systems. In Seligman C, Olson JM and Zanna MP (Eds.), The psychology of values: The Ontario symposium: 124. Erlbaum, Hillsdale, New Jersey, USA.

Schwartz SH and Bilsky W (1990). Toward a theory of the universal content and structure of values: Extensions and cross-cultural replications. Journal of Personality and Social Psychology, 58(5): 878-891.

Schwartz SH and Boehnke K (2004). Evaluating the structure of human values with confirmatory factor analysis. Journal of Research in Personality, 38(3): 230-255.

Schwartz SH, Melech G, Lehmann A, Burgess S, Harris $\mathrm{M}$ and Owens V (2001). Extending the cross- 
cultural validity of the theory of basic human values with a different method of measurement. Journal of Cross-Cultural Psychology, 32(5): 519542.

Warnock M and Norwich B (2010). 2nd Edition, Bloomsbury Academic, London, UK.
Wiersma SR, Ortega J, Sobel E and Weinberg KI (1991). Clinical importance of myeloid-antigen expression in acute lymphoblastic leukemia of childhood. New England Journal of Medicine 324(12): 800-808.

Wiersma W (2000). Research Methods in Education. Pearson, Needham Height, USA. 